\title{
A NEW FINDING OF THE NON-NATIVE COPEPOD SINODIAPTOMUS SARSI (COPEPODA, CALANOIDA, DIAPTOMIDAE) IN UKRAINE
}

\author{
L. Svetlichny ${ }^{1}$, L. Samchyshyna ${ }^{2,3}$ \\ ${ }^{1}$ Schmalhausen Institute of Zoology NAS of Ukraine, \\ vul. B. Khmelnytskogo, 15, Kyiv, 01030 Ukraine \\ E-mail: Leonid Svetlichny<leonid.svetlichny@gmail.com \\ ${ }^{2}$ Institute of Fisheries, National Academy of Agrarian Sciences, \\ vul. Obukhivska, 135, Kyiv, 03164 Ukraine \\ ${ }^{3}$ Institute of Fisheries and Marine Ecology, \\ Konsulska st., 8, Berdiansk, 71118 Ukraine \\ E-mail: Leonid Svetlichny<leonid.svetlichny@gmail.com \\ L. Svetlichny (https://orcid.org/0000-0001-9224-6371) \\ L. Samchyshyna (https://orcid.org/0000-0002-3816-2641)
}

\begin{abstract}
A New Finding of the Non-Native Copepod Sinodiaptomus sarsi (Copepoda, Calanoida, Diaptomidae) in Ukraine. Svetlichny, L., Samchyshyna, L. - Sinodiaptomus sarsi (Rylov, 1923) was found for the second time in Ukraine, in three artificial lakes located in the park Nyvki, Kyiv City, after its first record in the Carpathian Mountain region near Slovakian border in 2016. Our morphological study showed the similarity between the specimens of $S$. sarsi found in Kyiv with the existing illustrations and descriptions of the species. The most likely route of invasion is through human unwary release. The morphology of the new population is here described.

Key words: Copepoda, Calanoida, Diaptomidae, Sinodiaptomus, Europe, Ukraine, invasion.
\end{abstract}




\section{Introduction}

Sinodiaptomus sarsi (Rylov, 1923) was recently recognized as a "growing" species in Europe (Battes et al., 2020), which becomes evident after several finds here in recent years (Mykitchak, 2016; Battes et al., 2020; Podshivalina \& Sheveleva, 2020). Biological invasions appear to be occurring at an increasing rate, and a number of non-indigenous species are expanding their distributions across the world (e. g., Dexter \& Bollens, 2020). The well-documented European waterways suitable as invasion corridors for aquatic taxa (Grigorovich et al., 2002; Alexandrov et al., 2007; Galil et al., 2008) have been supplemented in recent decades by the Asian colonization of Europe by non-indigenous zooplankton species, due to the strengthening of economic exchange between the countries of these regions (Turbelin et al., 2017). At least four cyclopoid (Temnykh \& Nishida, 2012; Anufrieva et al., 2014; Anufrieva \& Shadrin, 2016), four calanoid copepod species (Alfonso et al., 2014; Sabia et al., 2014; Mykitchak \& Koval, 2018) native to Asian region, one to Australia (Ferrari \& Rossetti, 2006) and one to North America (Branford et al., 2017) have been reported in recent years as new to Europe. Such risks of invasion raise up with the increasing of human international economic activity, especially for small animals such as copepods which can be easily transported along with plants, feather of birds or in the intestines of fish (Havel \& Shurin, 2004, Bartholme et al., 2005). Known vectors of long-distance translocation of so-called "hitchhiking" nonnative zooplankton taxa include the association with fish of commercial interest utilized in aquaculture (Duggan \& Pullan, 2017, Pearson \& Duggan, 2018) or the aquarium trade (Duggan, 2010).

The original description of $S$. sarsi was carried out by Rylov (1923), based on specimens collected in the neighborhood of Harbin in northern China. He described this new taxon as a subspecies Diaptomus chaffanjoni var. sarsi. Later, Kiefer (1928) elevated its rank to species level. However, according to article 45.6.4 of the International Code of Zoological Nomenclature, if a taxon of infrasubspecific rank was established before 1961, it has to be considered of subspecific rank (ICZN, 1999).

Populations of this species, which are native to northern and central China, Japan, Korea, Mongolia, and southeastern Russia (Borutzky, Stepanova, Kos, 1991), were later recorded further to the west, as in central and western Asia, e. g., in the Caucasus region (Rylov, 1930; Weisig, 1931; Kasymov, 1972), Kazakhstan (Sharapova, 1989), and western Iran (Löffler, 1961; Smagowicz, 1976), where the species is considered autochthonous by Marrone et al. (2017). In the last decades it was also found in southeastern Turkey (Gündüz, 1998; Ustaoğlu, 2004; Bekleyen, 2006). In 1997, S. sarsi was recorded at East Siberia for the first time (Afonina \& Itigiliva, 2010) in steppe cooling pond of the Charanorskoye power plant located on the Onon River in the watershed of the upper Amur River. Within Russian Federation, it was found in Dagestan, in Krasnodar area, in the Far East (Borutzky et al., 1991), and on Bering Island (Novichkova \& Chertoprud, 2015). Yusifov et al. (2017) reported that S. sarsi was widespread in water bodies of Azerbaijan plains. New locations of the species were found also in Kazakhstan (Krupa \& Saparov, 2010, Krupa \& Mullabaev, 2010). Recently, S. sarsi was recorded in north-eastern Romania (Battes et al., 2020) and in the Middle Volga Region (Podshivalina \& Sheveleva, 2020). In Ukraine, few specimens of $S$. sarsi were found in 2016 in the lake of Novostuzhytske forestry and trout farm old pond both located in the watershed of the upper Uzh River in the Carpathian Mountains (Mykitchak, 2016, 2018; Mykitchak \& Koval, 2018).

This paper presents a new finding of a population of $S$. sarsi in Kyiv, central Ukraine, in September and October 2020. The morphology of the new population is described.

\section{Material and methods}

Zooplankton samples were collected by horizontal subsurface tows of $10 \mathrm{~m}$ using a plankton net with a $100 \mu \mathrm{m}$ mesh and mouth diameter of $0.3 \mathrm{~m}$ in eight artificial water bodies located on the tributaries of the Dnipro River in Kyiv Region: Bucha (General Lakes), Lybyad (Belichanskoye Lake), Syrets (three lakes in the Nyvky Park), Sovka (south-eastern and south-western ponds) and Orekhovatka (eastern pond) from August 15 to October 15, 2020. Temperature of water varied from 17 to $13{ }^{\circ} \mathrm{C}$. Volume of filtered water was approximately $0.7 \mathrm{~m}^{-3}$ for each tow, and 3-5 tows were carried out for each investigated water body. After about an hour, the collected samples were sorted, and all live specimens of Sinodiaptomus were transferred into fresh filtered water. Morphological studies were performed to confirm the species identification of collected specimens. An anesthetized by MS222 individuals were dissected and studied with LOMO BIOLAM C11 stereomicroscope equipped with Nikon 1J5 camera. Photos were done by Dr. L. Svetlichny. The collected and studied material was identified by Dr. L. Svetlichny, females and males of S. sarsi were fixed in $96 \%$ ethanol and deposited at the Depository of Institute of Zoology NASU in separate storage vessels.

The identification of the species is based on original descriptions by Rylov $(1923,1930)$ and redescription by Ueda \& Ohtsuka (1998). 


\section{Results}

Sampling activities

Among all sampled sites, S. sarsi was found only in three artificial ponds of Nyvky park (table 1) on the following dates: September 16, 2020 (12 females with egg sacs and 10 males; October 4 (5 females with egg sacs and 21 males); on October 15 ( 7 females ( 1 with egg sac), 13 males, and 13 copepodites).

Sinodiaptomus sarsi (Rylov, 1923)

Redescription. Female (fig. 1, A). Body length (excluding furcal setae) 2.05-2.49 $\mathrm{mm}(2.24 \pm 0.13 \mathrm{~mm}, \mathrm{n}=15)$, prosome length $1.45-1.75 \mathrm{~mm}(1.58 \pm 0.09 \mathrm{~mm})$, prosome width $0.51-0.65 \mathrm{~mm}(0.58 \pm 0.04 \mathrm{~mm})$. The dorsal surface of last prosomal somite with a chitinous, triangular projection (fig. $1, A$ ), which is a diagnostic character of the genus Sinodiaptomus (Kiefer, 1932). This somite with moderately developed wings. Left wing twolobed with inner one round. Right wing relatively pointed. Both lobes with strong hyaline spine (fig. 2). Urosome with three somites, genital somite slightly asymmetrical, with a moderately long hyaline spine on each side, the intermediate somite short. Antennules extending beyond the caudal setae (fig. 1, A). Coxopodite of leg 5 with long, strong, distolateral projection (fig. 3, arrow).

Male (fig. 1, B). Body length 1.9-1.95 mm $(1.91 \pm 0.02 \mathrm{~mm}, \mathrm{n}=20)$, prosome length $1.20-1.32 \mathrm{~mm}(1.25 \pm 0.04 \mathrm{~mm})$, prosome width $0.45-0.48 \mathrm{~mm}(0.46 \pm 0.02 \mathrm{~mm})$. Urosome has a lateral bend to the right. Antennules reach the end of caudal rami. Right antennule geniculated between segments 18 and 19; segment 15 (fig. 4) with longer projection than that of segment 14; antepenultimate segment of right male antennule with a comb-like process (fig. 4). Basipodite of right leg 5 with a wide round process reaching almost the distal end of the exopodite I and with a hyaline lamella on its distal inner margin (fig. 5). Exopodite II of left leg 5 ending in a lamellate thumb-like process with short posterodistal basal projection.

\section{Discussion}

In general, the morphological characters of the specimens found in Kyiv are identical to those described for the native populations of Sinodiaptomus sarsi from Asia (Rylov, 1923; Kiefer, 1978; Ueda \& Ohtsuka, 1998). We only noticed that, in our samples, antennules of males were a bit shorter than described elsewhere and did not go beyond the caudal rami.

The highest number of individuals was recorded on October 15th 2020, when the density of $S$. sarsi increased to 5.2 ind $\mathrm{m}^{-3}$ and copepodites appeared in the water. In September 2020, a lot of females with egg sacs were observed in the ponds.

The spread of $S$. sarsi is likely facilitated by the fact that its life cycle includes a diapausing egg phase. Gündüz (1998) believed that this species was introduced in East Anatolia from western Iran (probably from Zaribar Lake). He has also predicted that S. sarsi may eventually migrate to Europe by using Anatolia as a bridge between Asia and Europe. Battes et al. (2020) considered that the fish stocking may represent the main vector of $S$. sarsi introduction in Romania and Ukraine.

Table 1. Sampling data characteristic at artificial ponds of Nyvky park in Kyiv

\begin{tabular}{|c|c|c|c|c|c|}
\hline Date & $\begin{array}{c}\text { Latitude } \\
\left({ }^{\circ} \mathrm{N}\right)\end{array}$ & $\begin{array}{c}\text { Longitude } \\
\left({ }^{\circ} \mathrm{E}\right)\end{array}$ & $\begin{array}{c}\text { Water } \\
\text { temperature }\end{array}$ & Number of individuals & $\begin{array}{l}\text { Density, } \\
\text { ind } \mathrm{m}^{-3}\end{array}$ \\
\hline 16.09.2020 & $50^{\circ} 27^{\prime} 38^{\prime \prime}$ & $30^{\circ} 24^{\prime} 38^{\prime \prime}$ & 17.1 & 12 o, 10 ○ & 3.5 \\
\hline 04.10 .2020 & « « & « « & 14.5 & 5 ९, $21 \sigma^{7}$ & 4.1 \\
\hline 15.10 .2020 & « « & $\ll \ll$ & 12.9 & 7 o, 13 o', 13 CI-CV & 5.2 \\
\hline
\end{tabular}



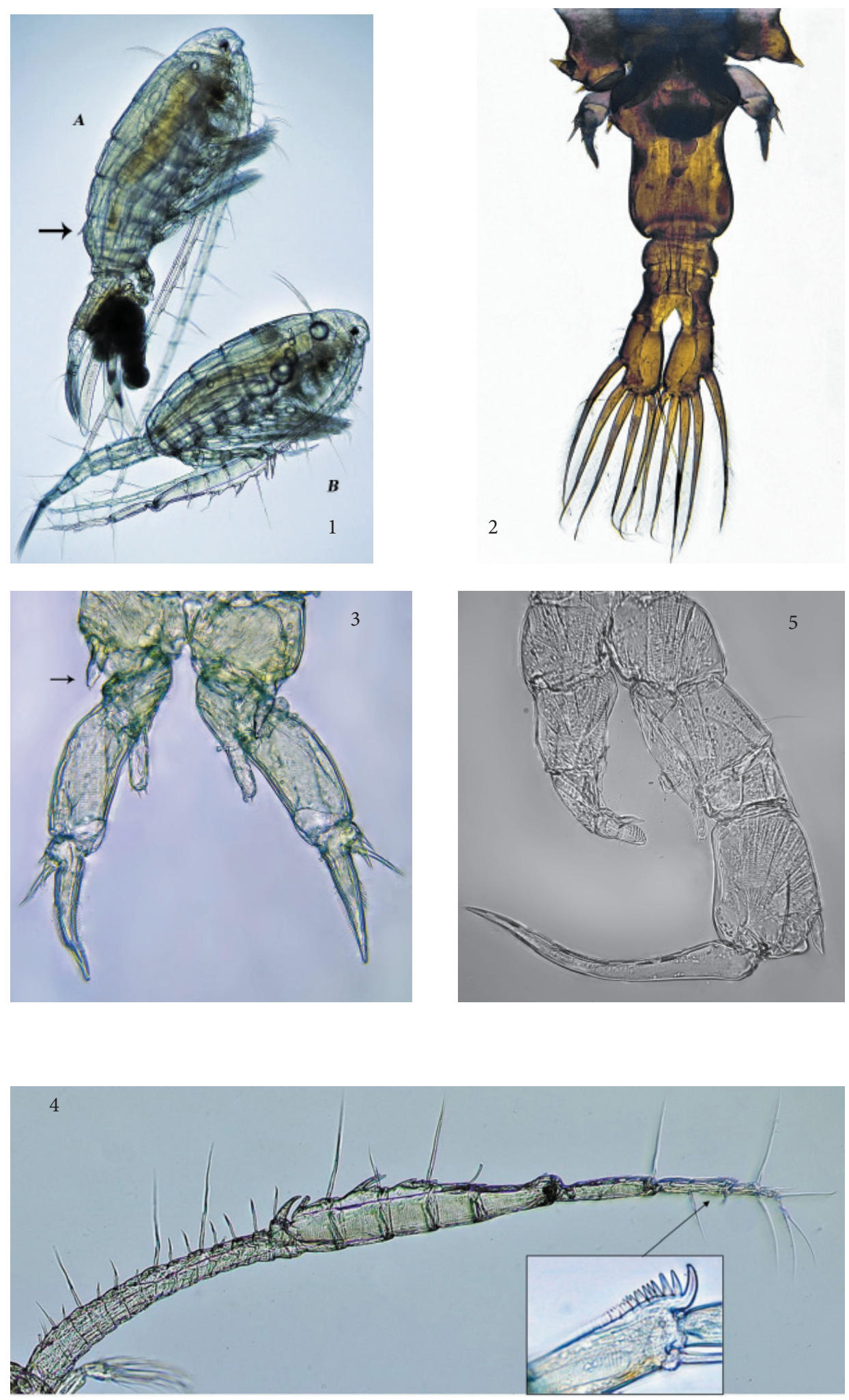

Figs 1-5. Sinodiaptomus sarsi: 1 - habitus of female (A) and male (B); 2 - last prosomal somite and urosome of female; 3 - leg 5, female; 4 - right antennule, male; $5-\operatorname{leg} 5$, male. 
However, nowadays, the volume of commercial exchanges between different countries has increased and speeded up so much that the translocation of alien species between even distantly-located regions becomes more and more likely, both through intentional or accidental releases. Aquaculture is currently the fastest growing animal food production sector in the world (De Silva et al., 2009). Fish farming is currently dominated by Asian countries, which produced 89 percent of the global total production in volume terms in the last 20 years (FAO, 2020). The import of fish, fish derivate and other aquatic bioresources to Ukraine amounted to 399.1 thousand tons in 2019 (Public report..., 2019). Furthermore, China has remained a top fish producer in the world, accounting for 35 percent of global fish production in 2018 $(\mathrm{FAO}, 2020)$ and it is exporting a large amount of fish and aquaculture production to Ukraine (Public report..., 2019). In spite of the cogent fact that zooplankton invasions have implicated the aquaculture industry as the vector for introduction (Duggan \& Pullan, 2017), unfortunately, there are no papers describing the zooplankton taxa residing in Chinese aquaculture farms, which is a significant knowledge gap in zooplankton diversity in aquaculture ponds for the most productive country in the world (Pearson \& Duggan, 2018). It is interesting to note that in Kyiv S. sarsi, was found only in three interconnected ponds of Nyvky park. These ponds are located at the source of the Syrets River and are surrounded by numerous retail outlets, including a pet and aquarium store, and oriental restaurant with the symbolic name "EURASIA". The other investigated ponds built on the nearby rivers (i. e., Bucha, Lybyad, Sovka, and Orekhovatka) are less surrounded by commercial or industrial constructions, and S. sarsi specimens were not found there in spite of an intensive sampling campaign. Previously, the monitoring of the zooplankton of the water bodies of Kyiv, including the ponds of Nyvki park, was carried out within the framework of various ecological programs mostly funded by Institute of Hydrobiology, Institute of Zoology and Institute for Evolutionary Ecology of National Academy of Sciences of Ukraine (Monchenko,1956; Kostenko \& Monchenko, 1982; Gromova, 1998; Rybka \& Zaichenko, 2012; Smolensky, 2014; Volikov \& Rybka, 2015; Samchyshyna \& Dubrovsky, 2015, etc.). However, until 2020, S. sarsi had not been recorded in the samples of zooplankton from water bodies of Kyiv City and neighboring areas. We believe that appearance of this Asian species should be considered as a recent and accidental release of the species along with waste or sewage waters from either the nearby exotic restaurant or the pet and aquarium store. It is known from papers on zooplankton in the aquarium trade what non-indigenous species had a greater probability of being recorded in aquaria containing aquatic plants and in those that were heated. Methods for disposal of aquarium wastes ranged from depositing washings on the lawn or garden (a low risk for invasion) to disposing of water into outdoor ponds or storm-water drains (a higher risk) (Duggan, 2010). Since females bearing egg sacs were observed in the samples collected in the autumn, the population of $S$. sarsi may successfully overwinter and establish as a permanent dweller in the studied ponds, from which the invader can penetrate into the Dnipro River via its tributary Syrets River, via Kyrylovske Lake, and Pochaina River. The spreading of this non-native species might have a detrimental effect on native zooplankton taxa, community, and even ecosystem structure. The realisation of a systematic monitoring of the water bodies of this area as well as a detail taxonomic survey of zooplankton from aquaculture farms in Ukraine are thus highly desirable.

This work was supported by the project of the NASU (grant number 0114U002041). We sincerely thank the three anonymous referees for useful comments and corrections that improved greatly this manuscript. 


\section{References}

Afonina, E. Yu, Itigiliva, M. Ts., 2010. Sinodiaptomus sarsi (Rylov, 1923) (Copepoda: Calanoida) — the first record from East Siberia In: Slynko, Yu., Dgebuadze, Yu. \& Krylov, A. eds. Invasion of alien species in Holarctic. Print-House Publ. Co, Borok-Myshkin, 31-32.

Alexandrov, B., Boltachev, A., Kharchenko, T., Lyashenko, A., Son, M., Tsarenko, P., Zhukinsky, V. 2007. Trends of aquatic alien species invasions in Ukraine. Aquatic Invasions, 2 (3), 215-242.

Alfonso, G., Russo, R., Belmonte, G. 2014. First record of the Asian diaptomid Neodiaptomus schmackeri (Poppe et Richard, 1892) (Crustacea: Copepoda: Calanoida) in Europe. Journal of Limnology, 73 (3), 584-592.

Anufrieva, E., Hołyńska, M., Shadrin, N. 2014. Current invasions of Asian Cyclopid species (Copepoda: Cyclopidae) in Crimea, with taxonomical and zoogeographical remarks on the hypersaline and freshwater fauna. Annales Zoologici, 64, 109-130.

Anufrieva, E., Shadrın, N. 2016. Current invasions of East Asian cyclopoids (Copepoda, Cyclopoida) in Europe: new records from eastern Ukraine. Turkish Journal of Zoology, 40 (2), 282-285.

Bartholmé, S., Samchyshyna, L., Santer, B., Lampert, W. 2005. Subitaneous eggs of freshwater copepods pass through fish guts: Survival, hatchability, and potential ecological implications. Limnology and Oceanography, 50 (3), 923-929.

Battes, K. P., Váncsa, É., Barbu-Tudoran, L., Cîmpean, M. 2020. A species on the rise in Europe: Sinodiaptomus sarsi (Rylov, 1923) (Copepoda, Calanoida), a new record for the Romanian crustacean fauna. BioInvasions Records, 9 (2), 320-332.

Bekleyen, A. 2006. Devegecidi Baraj, Cladocera and Copepoda fauna (Crustacea) of Devegeçidi Dam Lake (Diyarbakır). EU Journal of Fisheries \& Aquatic Sciences, 23 (3-4), 413-415 [In Turkish].

Borutzky, E. V., Stepanova, L. A., Kos, M. S. 1991. Key to freshwater Calanoida of the USSR. Opredelitel Calanoida Presnykh Vod SSSR. Nauka, St. Petersburg, 1-503 [In Russian].

Branford, S. N., Duggan, I. C., Hogg, I. D., Brandorff, G. O. 2017. Mitochondrial DNA indicates different North American east coast origins for New Zealand and German invasions of Skistodiaptomus pallidus (Copepoda: Calanoida). Aquatic invasions, 12, 167-175.

De Silva, S. S., Nguyen, T. T., Turchini, G. M., Amarasinghe, U. S., Abery, N. W. 2009. Alien species in aquaculture and biodiversity: a paradox in food production. Ambio, 38 (1), 24-8.

Dexter, E., Bollens, S. M. 2020. Zooplankton invasions in the early 21 st century: a global survey of recent studies and recommendations for future research. Hydrobiologia, 847, 309-319.

Duggan, I. C. 2010. The freshwater aquarium trade as a vector for incidental invertebrate fauna. Biological Invasions, 19, 307-314.

Duggan, I. C., Pullan, S. 2017. Do freshwater aquaculture facilities provide an invasion risk for zooplankton hitchhikers? Biological Invasions, 12, 3757-3770.

FAO. 2020. The State of World Fisheries and Aquaculture 2020. Sustainability in action. Rome, 1-244. [Electronic resource] : Mode of access : http://www.fao.org/documents/card/en/c/ca9229en (viewed on 10.11.2020). Title from the screen.

Ferrari, I., Rossetti, G. 2006. New records of the centropagid Boeckella triarticulata (Copepoda: Calanoida) in Northern Italy: evidence of a successful invasion? Aquatic Invasions, 1, 219-222.

Galil, B. S., Nehring, S., Panov, V. 2008. Waterways as Invasion Highways - Impact of Climate Change and Globalization. In: Nentwig, W., eds. Biological Invasions. Ecological Studies (Analysis and Synthesis). Springer, Berlin, 1-193.

Grigorovich, I. A., MacIsaac, H. J., Shadrin, N. V., Mills, E. L. 2002. Patterns and mechanisms of aquatic invertebrate introductions in the Ponto-Caspian region. Canadian Journal of Fisheries and Aquatic Sciences, 59 (7), 1189-1208.

Gromova, Yu. F. 1998. The structure of zooplankton community of mouth area of Vita River in recreation territory of Kyiv. In: Andronati, S. A. et al., eds. Ekologiia gorodov i rekreatcionnyh zon. Astroprint, Odessa, 38-40 [In Russian].

Gündüz, E. 1998. Sinodiaptomus sarsi (Rylov, 1923) (Copepoda, Calanoida) in Turkey. Hydrobiologia, 380, 9-13.

Havel, J. E., Shurin, J. B. 2004. Mechanisms, effects, and scales of dispersal in freshwater zooplankton. Limnology and Oceanography, 4 (2), 1229-1238.

ICZN. 1999. International Code of Zoological Nomenclature, 4th Edition. International Trust for Zoological Nomenclature, c/o The Natural History Museum, London, 1-306.

Kasymov, A. G. 1972. The freshwater fauna of Caucasus. ELM, Baku, 1-286 [In Russian].

Kiefer, F. 1928. Beiträge zur Copepodenkunde (IX). Zoologischer Anzeiger, 76 (1/2), 99-110 [In German]. 
Kiefer, F. 1932. Versuch eines Systems der altweltlichen Diaptomiden (Copepoda Calanoida). Zoologischer Anzeiger, 100, 213-220 [In German].

Kiefer, F. 1978. Das Zooplankton der Binengewasser 2. Teil, Freilebende Copepoda. E. Schweizerbant sche Verlasbuchhandlung, Stuttgart, 1-380 [In German].

Kostenko, S. M., Monchenko, V. I. 1982. On community of peritrich infusoria (Peritricha, Sessilina) of cyclopoids in Kyiv vicinity. In: Pavlovekov, E. N., eds. Recent problems of parasitology. Vilnus, 237.

Krupa, E. Y., Saparov, K. A. 2010. Zooplankton of south Kazakhstan. Vestnik Karakalpakskogo otdeleniia Academii Nauk Republiki Uzbekistan, 2, 21-24 [In Russian].

Krupa E. Y., Mullabaev, N. H. 2010. Strukture of zooplankton of reservoirs of south Kazakhstan and Zhambyl province of Kazakhstan. Uzbek Biological Journal, 1, 50-53 [In Russian].

Löffler, H. 1961. Beitrage zur Kenntnis der iranischen Binnengewässer II. Regionallimnologische Studie mit besonderer Berücksichtigung der Crustaceenfauna. Internationale revue der gesamten hydrobiologie und hydrographie., 46, 309-406 [In German].

Marrone, F., Alfonso, G., Naselli-Flores, L., Stoch, F. 2017. Diversity patterns and biogeography of Diaptomidae (Copepoda, Calanoida) in the Western Palearctic. Hydrobiologia, 800, 45-60.

Monchenko, V. I. 1956. New for Kyiv region species of Copepoda. Studentski naukovi pratci KDU, 20, 63-66 [In Russian].

Mykitchak, T. 2016. Checklist and distribution of Cladocera and Copepoda (Calanoida, Cyclopoida) from the Ukrainian Carpathians. Journal of Wetlands Biodiversity, 6, 109-121.

Mykitchak, T. 2018. A preliminary annotated checklist of Calanoida and Cyclopoida (Crustacea) of Ukrainian Carpathions. Studia Biologica, 12/N 2, 87-98 [In Ukrainian.]

Mykitchak, T., Koval, N. 2018. Cladocera and Copepoda crustaceans of the Upper Uzh River (Ukrainian Carpathians). Visnyk of the Lviv University. Series Biology, 77, 129-136 [In Ukrainian].

Novichkova, A. A., Chertoprud, E. S. 2016. The freshwater crustaceans (Cladocera: Copepoda) of Bering Island (Commander Islands, Russian Far East): species richness and taxocene structure. Journal of Natural History, 50 (21-22), 1357-1368.

Public report of the State Fisheries Agency of Ukraine. 2019. [Electronic resource] : Mode of access: https://darg. gov.ua/_publichnij_zvit_derzhavnogo_0_0_0_9463_1.html (viewed on 12.11.2020). — Title from the screen.

Pearson, A., Duggan, I. C. 2018. A global review of zooplankton species in freshwater aquaculture ponds: What are the risks for invasion? Aquatic Invasions, 13, 311-322.

Podshivalina, V. N. Sheveleva, N. G. 2020. First record of Sinodiaptomus sarsi (Copepoda: Calanoida) from the East European Plain. Zoosystematica Rossica, 29 (1), 60-69 [In Russian].

Rybka, T. S., Zaichenko, N. V. 2012. Zooplankton of some water objects of urban areas in Kiev. Naukovi zapysky of Volodymyr Hnatiuk TNPU. Seria Biologia, 4 (53), 45-50 [In Ukrainian].

Rylov, V. M. 1923. On the Crustacea-Eucopepoda fauna of Manchuria. Annuaire du Musée Zoologique de l'Académie des Sciences de Russie, 24, 52-95, plates 1-3 [In Russian].

Rylov, V. M. 1930. The fresh-water Calanoids of the U.S.S.R. In: Bening, L. A. et al., eds. Opredeliteli organizmov presnyh vod SSSR. VASHN, Leningrad, 1-288 [In Russian].

Sabia, L., Uttieri, M., Schmitt, F. G., Zagami, G., Zambian-chi, E. et al. 2014. Pseudodiaptomus marinus Sato, 1913, a new invasive copepod in Lake Faro (Sicily): observations on the swimming behaviour and the sexdependent responses to food. Zoological Studies, 53, 49.

Samchyshyna, L, Dubrovsky, Yu. 2015. Cladoceran assemblage of Kyiv small water bodies: results of monitoring in 2010-2011. Naukovi zapysky of Volodymyr Hnatiuk TNPU, 3-4 (64), 791-793.

Sharapova, L. I. 1989. The state of zooplanktocenosis of lower delta of the Ile River under the anthropogenic impact. AlmaAta, 12 p. Dep. in KazNIINTI 12.05.89, 2885 Ka-89 [In Russian].

Smagowicz, K., 1976. On the zooplankton of Lake Zeribar, western Iran. Acta Hydrobiologica, 18, 89-100.

Smolensky, O. 2014. The structure of zooplankton community of Kyiv region. Pryroda Zahidnogo Polissia ta pryleglyh terytorii, 11, 244-248 [In Ukrainian].

Temnykh, A. Nishida, S. 2012. New record of copepod Oithona davisae Ferrari and Orsi in the Black Sea with notes on the identity of "Oithona brevicornis". Aquatic Invasions, 7, 425-431.

Turbelin, A. J., Malamud, B. D., Francis, R. A. 2017. Mapping the global state of invasive alien species: patterns of invasion and policy responses. Global Ecology and Biogeography, 26, 78-92.

Ueda, H., Ohtsuka, S. 1998. Redescription and taxonomic status of Sinodiaptomus valkanovi, a common limnoplanktonic calanoid copepod in Japan, with comparison to the closely related S. sarsi. Hydrobiologia, 379, 159-168.

Ustaoğlu, M. R. 2004. A check-list for zooplankton of Turkish inland waters. Journal of Fisheries and Aquatic Sciences, 21, 191-199. 
Volikov, Yu. N., Rybka, T. S. 2015. Ecological and sanitary condition of main riverbed Kyiv part of Kanevskogo reservoir on macrozoobenthos and zooplankton idicators. Naukovi zapysky of Volodymyr Hnatiuk TNPU, Seria Biologia, 3/4 (64), 100-103 [In Ukrainian].

Weisig, S. 1931. Diaptomus atropatenus sp. nov. Miteinem Beitrag ueber diaptomidenfauna des oestlich Transkaukasiens. Zoologischer Anzeiger, 95, 255-262 [In German].

Yusifov, E. F., Alekperov, I. Kh., Ibrahimov, Sh. R., Aliyev, A. R., Guliyev, G. N., Mustafayev, N. J., Babayev, I. R., Aliyev, S. I., Gasimova, G. H., Taghiyeva, K. Y. 2017. About the biological diversity of inland water ecosystems in Azerbaijan. Proceedings of ANAS (Biological and Medical Sciences), 72 (3), 74-91.

Received 17 November 2020

Accepted 5 January2021 